\title{
Adverse Event Category Code
}

National Cancer Institute

\section{Source}

National Cancer Institute. Adverse Event Category Code. NCI Thesaurus. Code C93708.

A coded value specifying a classification of the adverse event. 